\title{
FAKTOR-FAKTOR DETERMINASI NARKOLEMA PADA REMAJA
}

\author{
Siswanto $^{1}$, Wahyu Purwaningsih ${ }^{2}$ \\ ${ }^{1}$ Akademi Keperawatan Insan Husada Surakarta \\ ${ }^{2}$ Sekolah Tinggi Ilmu Kesehatan 'Aisyiyah Surakarta \\ siswantoarizal@gmail.com, wahyuikd@gmail.com
}

\begin{abstract}
Abstrak
Pendahuluan: Masa remaja merupakan suatu tahap dengan perubahan yang cepat dan penuh tantangan yang sulit. Pemahaman tentang narkolema yang kurang pada masa remaja sangat merugikan bagi remaja sendiri termasuk keluarganya. Kejadian narkolema tersebut dapat dipengaruhi oleh beberapa faktor diantaranya adalah sikap individual, kontrol diri pada remaja, peran pengawasan orang tua.Individu yang mempunyai sikap negatif terhadap media pornografi beranggapan bahwa pornografi dapat memberiakan manfaat yang baik dan meberikan inspirasi bagi individu, sehingga individu mempunyai perasaan suka terhadap pornografi dan dapat membawa ke perilaku seksual. Seseorang yang mengalami narkolema akan sulit untuk mengontrol dirinya dan akan mengalami gangguan memori Interaksi antara remaja dengan orang tua mengurangi kejadian narkolema pada remaja. Orang tua yang kurang memberikan pengawasan kepada remaja akan mempercepat remaja tersebut untuk terjadinya narkolema dan begitu pula sebaliknya.
\end{abstract}

Tujuan: Mengambarkan faktor determinan yang mempengaruhi narkolema pada remaja.

Metode: Jenis penelitian deskriptif dengan populasi sebanyak 668 orang, diambil sampel 250 orang dengan teknik Stratified Random Sampling. Instrumen penelitian menggunakan lembar kuesioner.Data dianalisis dengan distribusi frekuensi.

Hasil: Siswa mengalami narkolema sebanyak 163 siswa $(65,2 \%)$, sikap individual siswa dalam kategori buruk sebanyak 175 remaja (70\%), kontrol diri siswa baik sebanyak 168 responden (67\%), peran pengawasan orang tua baik sebanyak 188 orang $(75,2 \%)$. Kesimpulan: Sebagian besar siswa mengalami narkolema, Sikap individual remaja yang mengalami narkolema termasuk dalam kategori buruk. Kontrol diri pada remaja mayoritas baik. Peran pengawasan orang tua terhadapan anak terkait dengan narkolema tergolong baik

Kata kunci: kejadian narkolema, faktor-faktor terjadinya narkolema

\section{Abstract}

Introduction: Adolescence is a stage of rapid change and full of difficult challenges. The lack of understanding of narcolema in adolescence is very detrimental to adolescents themselves, including their families. The occurrence of narcolema can be influenced by several factors including individual attitudes, self-control in adolescents, the role of parental supervision. Individuals who have negative attitudes toward pornography media assume that pornography can provide good benefits and provide inspiration for individuals, so individuals have feelings like against pornography and can lead to sexual behavior. Someone who experiences narcolema will be difficult to control himself and will experience memory disorders Interaction between teenagers with parents reduces the incidence of narcolema in adolescents. Parents who do not provide supervision to adolescents will accelerate adolescents to narcolema and vice versa. 
Objective: To describe the determinant factors that influence narcolema in adolescents. Method: Descriptive research type with a population of 668 people, a sample of 250 people was taken with the Stratified Random Sampling technique. The research instrument used questionnaire sheets. Data were analyzed by frequency distribution. Results: Students experienced narcolema as many as 163 students (65.2\%), individual attitudes of students in the bad category were 175 adolescents (70\%), students selfcontrol were 168 respondents (67\%), the role of supervision of good parents was 188 people ( $75.2 \%)$.

Conclusion: Most students experience narcolema, the attitudes of adolescent individuals who experience narcolema are included in the bad category. Self-control in the majority of teens is good. The role of parental supervision of children related to narcolema is quite good

Keywords: narcolema occurrence, narcolema occurrence factor.

\section{Pendahuluan}

World Health Organizations (WHO) mengemukakan bahwa batasan umur yang di anggap remaja yaitu berusia 10 sampai 20 tahun. Menurut WHO (1995) sekitar seperlima dari penduduk dunia adalah remaja berumur 10-19 tahun. Sekitar 900 juta berada di negara sedang berkembang salah satunya di Indonesia. Masa remaja merupakan masa individu beralih dari masa kanak-kanak menuju dewasa, dimana remaja memulai eksplorasi seksual dan mengintegrasikan seksual kedalam identitas dirinya. Kehadiran media komunikasi serta perkembangan teknologi komunikasi dan informatika yang kini semakin pesat, mempermudah dan memperbanyak penyebaran materi pornografi. Di Indonesia materi pornografi sangat mudah diakses di berbagai kalangan, terutama kalangan para remaja (Nurhayanti, dkk, 2016).

Yufita et al., (2015) mengemukakan bahwa di 12 kota terbesar di Indonesia sebanyak $83 \%$ remaja pernah mengaku menonton video porno. Perilaku remaja juga di dapatkan sebanyak 93,7\% pernah melakukan hubungan seksual dan $21 \%$ atau 1 di antara 5 remaja di Indonesia pernah melakukan aborsi. Hasil penelitian Wulandari (2017), yang di lakukan di SMK Negeri 7 Surakarta mengemukakan bahwa prevalensi terjadinya narkolema dan motivasi kurang baik sebanyak 83 orang $(72,8 \%)$, lebih banyak di banding dengan remaja yang terjadi narkolema sebagian besar dengan motivasi baik sebanyak 37 orang $(26,8 \%)$.

Narkolema adalah pornografi yang dapat di akses manusia lewat mata yang dapat merusak otak. Karena itulah istilah narkolema digunakan, yang bisa disebut sebagai narkoba millenum baru (Katselman, 2015). Undang- Undang 
pornografi No. 44 tahun 2008 pasal 1 ayat 1 dalam Soebagijo (2009), pornografi adalah gambaran, sketsa, ilusi, foto, bunyi, tulisan, gambar bergerak, animasi kartun, percakapan, gerak tubuh dan pesan lainnya melalui berbagai bentuk media komunikasi yang membuat eksploitasi yang melangar norma keasusilaan di dalam masyarakat. Media pornografi bisa melalui beberapa jenis seperti tv, radio, internet, telpon dan komunikasi lainya serta surat kabar, majalah dan barang cetakan lainnya.

Berdasarkan hasil studi pendahuluan yang telah dilakukan oleh peneliti di 3 SMA di Kota Surakarta dengan jumlah kejadian narkolema sebagai berikut :

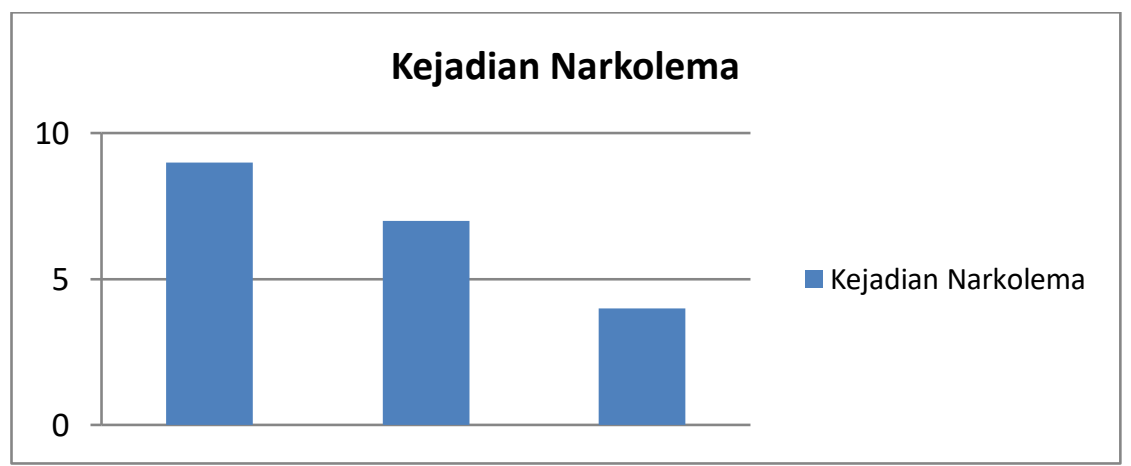

\section{Grafik 1.}

Distribusi jumlah kejadian narkolema pada 3 sekolah SMA di Kota Surakarta Januari - Februari 2018.

Kejadian narkolema tersebut dapat dipengaruhi oleh beberapa faktor diantaranya adalah sikap individual, kontrol diri pada remaja, peran pengawasan orang tua. Sikap seorang terhadap suatu objek merupakan perasaan mendukung atau memihak mampu perasaan tidak mendukung atau tidak memihak terhadap objek tersebut (Azwar, 2012). Sikap remaja terhadap pornografi merupakan yaitu sikap yang positif dan sikap yang negatif. Sikap positif bisa mengarah tindakan kecenderungan mendekati, menyenangi dan mengharapkan obyek tertentu. Sikap para remaja sejalan dengan pandangan masing-masing, ada yang menyatakan bahwa pornografi adalah hal yang terbuka tidak layak di tonton dan ada yang mengemukakan hal yang tidak layak di tonton (Susanto, 2013).Sikap negatif cenderung untuk menjauhi, tidak menyukai dan membenci obyek tertentu.Sikap yang baik lebih cenderung menjauhi, menghindari, membenci dan tidak menyukai objrk atau perilaku yang buruk. Individu yang mempunyai sikap positif terhadap 
pornografi tidak akan menyukai media pornografi, individu akan beranggapan bahwa media pornografi berbahaya dan akan membawa dampak perilaku yang tidak baik. Sikap yang buruk cenderung mendekati, menyenangi dan mengharapkan hal-hal yang buruk. Individu yang mempunyai sikap negatif terhadap media pornografi beranggapan bahwa pornografi dapat memberikan manfaat yang baik dan meberikan inspirasi bagi individu, sehingga individu mempunyai perasaan suka terhadap pornografi dan dapat membawa ke perilaku seksual (Dewi, 2011).

Selain sikap faktor internal lainnya yang mempengaruhi terjadinya narkolema adalah kontrol diri, dimana seseorang yang melihat narkolema akan sulit untuk mengontrol dirinya dan akan mengalami gangguan memori (Hilton dalam Nadesul, 2011).Hasil penelitian dari Aroma dan Suminar (2012), mengatakan bahwa seorang remaja yang mempunyai kontrol diri yang baik, maka remaja tersebut akan dapat menahan keinginan sesaat dan bisa berfikir logis bahwa perbuatannya akan menimbulkan kerugian pada dirinya. Seseorang dengan kontrol diri yang rendah mempunyai kecenderungan untuk menjadi implusif, senang melakukan tindakan yang beresiko dan melanggar aturan, dan biasanya memiliki pikiran yang sempit. Sedangkan seseorang yang memiliki kontrol diri yang tinggi biasanya mampu untuk menahan diri dari dorongan untuk berperilaku yang melanggar norma sosial. Berdasarkan hasil penelitian dari Khairunnisa (2013), mengatakan bahwa seseorang yang mempunyai agama dengan baik yang hanya untuk menyembah TuhanNya maka akan dapat meluruskan perilakunya, seseorang dapat mengontrol perilaku dengan kata lain meningkatkan kontrol dirinya. Kontrol diri berfungsi untuk membatasi individu bertingkah negatif. Tingkah laku negatif yang tidak sesuai dengan norma sosial tersebut adalah pornografi, kertergantungan pada obat atau zat kimia, rokok, dan alkohol. Perilaku tersebut akan berdampak negatif yaitu secara psikologis seperti rasa malu, kehamilan diluar nikah, dan penolakan oleh masyarakat. Narkolema juga berdampak pada perzinaan yaitu seperti pelecehan seksual, perkosaan, dan seks bebas.

Selain dari faktor internal faktor eksternal yang tak kalah penting dalam berkontribusi dalam terjadinya nerkolema pada remaja, salah satunya adalah 
pengawasan orang tua. Berdasarkan penelitian Hidayah \& Maryatun (2013), mengatakan bahwa pengawasan dari orang tua yang kurang dapat mempercepat anak mengalami kejadian pornografi. Pengawasan orang tua merupakan faktor penting yang mempengaruhi anak kecanduan dengan pornografi. Remaja yang diawasi orang tuanya akan menunda bahkan menghindari pornografi, sedangkan pada remaja tanpa pengawasan orang tua akan merasa bebas untuk mengakses pornografi dan bahkan melakukan hubungan seksual pada usia lebih dini.

Dampak yang akan timbul dari pornografi sangat beragam, dampak medis ponografi menyebabkan kerusakan otak, penyimpangan seksual, penyebaran penyakit menular seksual dan penyebaran HIV-AIDS. Ponografi yang memuat gambaran tentang eksploitasi seks dapat membuat sesorang kecanduan. Kondisi ini, jika tidak segera diatasi akan mengakibatkan rusaknya fungsi otak bagian depan, yaitu pre frontal cortex. Pre frontal kortex mempunyai fungsi sebagai kontrol diri, mengambil keputusan, mengatur emosi, mengorganisasi dan merencanakan (Soebagijo, 2009).

Berdasarkan data studi pendahuluan dari 10 siswa yang diberikan kuesioner didapatkan hasil 9 siswa menjawab terpapar pornografi. Berdasarkan data wawancara pada guru Bimbingan Konseling (BK) di salah satu SMA Negeri di Surakarta, pernah dilakukan razia handphone didapat beberapa siswa yang menyimpan video porno dan pada jam sekolah terdapat siswa sedang melihat atau menonton video porno pada handphonnya. Berdasar data tersebut mala tujuan penelitian ini adalah mengambarkan faktor determinan yang mempengaruhi narkolema pada remaja.

\section{Metode}

Jenis penelitian Jenis penelitian yang digunakan adalah deskriptif observasional. Penelitian deskriptif bertujuan untuk mendapatkan gambaran yang akurat dari sejumlah karakteristik masalah yang diteliti. Populasi yang digunakan dalam penelitian ini adalah siswa kelas X dan XI SMAN di Surakarta yaitu sebanyak 668 orang, diambil sampel sebanyak 250 dengan teknik Stratified Random Sampling. Data dikumpulkan melalui pengisian kuesioner yang telah divaliditas. Alat analisis yang digunakan dengan analisis univariat. Sebelum 
pengisian kuesioner peneliti melakukan informed consent ke siswa sebagai responden.

\section{Hasil dan pembahasan}

1. Distribusi frekuensi kejadian narkolema.

Tabel 1 Distribusi frekuensi kejadian narkolema di SMA Negeri di Surakarta bulan juli 2018

\begin{tabular}{cccc}
\hline No. & Kejadian & Frekuensi & Prosentase (\%) \\
& Narkolema & & 65,2 \\
1. & Narkolema & 163 & 34,8 \\
2. & Tidak narkolema & 87 & 100 \\
\hline & Total & 250 & siswa yang bersedia
\end{tabular}

menjadi responden dan mengikuti penelitian mayoritas terjadi narkolema sebanyak 163 siswa $(65,2)$. Berdasarkan observasi peneliti yang dilakukan dengan membagikan kuesioner yang berisi beberapa pernyataan yang mengenai narkolema sebanyak 163 remaja $(24,4 \%)$ responden kejadian narkolema. Berdasarkan item pernyataan minoritas responden mengetahui materi pornografi melalui teman sebaya dan media internet. Penelitian ini sesuai dengan pendapat Subagijo (2009) bahwa pola akses pada kaum muda atau remaja tidak lepas dari media masa dan teman sebaya.Peranmedia massa atau disebut dengan jendela informasi menyebabkan materi pornografi yang dapat dengan mudah di akses siapapun, cendrung lebih banyak menghabiskan waktu mereka bersama-sama teman sebaya dibandingkan bersama anggota keluarga atau sendirian.

Hasil penelitian yang di lakuakan oleh Masaroh (2015), menyebutkan remaja lebih banyak mengakses pornografi melalui media cetak dan media elektronik. Media elektronik yang paling sering di guanakn remaja mengunakan media elelktronik melalaui internet, jenis media pornografi yang di akses filem, video, foto komik dan majalah. Media elektronik dan media cetak tersebut dapat mempengarui pengetahuan dan sikap serta perilaku remaja. 
2. Distribusi frekuensi data sikap individual remaja

Tabel 2 Distribusi frekuensi sikap individual remaja di SMA Negeri Surakarta.

\begin{tabular}{lccc}
\hline No. & Sikap Individual & Frekuensi & Prosentase (\%) \\
\hline 1. & Baik & 75 & 30 \\
2. & Buruk & 175 & 70 \\
& Total & 250 & 100 \\
\hline
\end{tabular}

Berdasarkan distribusi dari tabel 2 diatas menujukan bahwa sikap individual dalam kategori buruk sebanyak 175 remaja (70\%).Hasil penelitian sikap individual di SMA Negeri di Surakarta menunjukkan sebagian besar remaja memiliki sikap buruk yaitu sebanyak 175 orang (70\%), sedangkan responden yang memiliki sikap baik hanya 75 orang (30\%).

Respon dalam bentuk afektif berupa perasaan individu terhadap objek sikap. Respon remaja terhadap akses media massa yang berkonten pornografi dimana individu yang mempunyai sikap positif terhadap media pornografi maka tidak akan menyukai pornografi. Individu akan beranggapan bahwa pornografi berbahaya dan akan berdampak yang tidak baik. Sebaliknya jika mempunyai sikap negatif terhadap media pornografi maka individu beranggapan bahwa pornografi bermanfaat dan memberikan inspirasi bagi perilaku individu, sehingga individu mempunyai perasaan suka (Susanto 2013).

Hasil penelitian Ruspawan (2013) disimpulkan bahwa sikap remaja sehubugan media pornografi sangat signifikan dengan perilaku pornografi. Masa remaja merupakan satu fase perkembangan yang dinamis dalam kehidupan individu, dimana masa tanmisi dari anak-anak ke masa remaja. Usia ini remaja masa perkembngan individu ditandai dengan pencarian identitas diri, dengan perkembangan satu pekerjaan.

3. Distribusi frekuensi data kontrol diri

Tabel 3 Distribusi Frekuensi Kotrol Diri remaja di SMA Negeri di Surakarta

\begin{tabular}{clcc}
\hline No & \multicolumn{1}{c}{ Kontrol Diri } & Frekuensi & Persentase (\%) \\
\hline 1. & Kurang baik & 82 & $33 \%$ \\
2. & Baik & 168 & $67 \%$ \\
& Total & 250 & $100 \%$ \\
\hline
\end{tabular}

Distribusi frekuensi kontrol diri responden menunjukkan distribusi tertinggi adalah baik yaitu sebanyak 168 responden (67\%) dan sisanya kurang baik sebanyak 82 responden (33\%). Berdasarkan hasil analisis tersebut, menunjukkan bahwa kontrol diri pada responden sebagian besar adalah baik. 
Salah satu faktor yang berhubungan dengan kontrol diri remaja yang cukup baik adalah tingkat pendidikan responden yang merupakan siswa-siswi dari SMA di Surakarta yang memiliki pola pembelajaran yang baik bagi siswanya termasuk memperhatikan perkembangan psikologis siswa.

Kontrol diri adalah bagaimana individu mengendalikan emosi dan perilaku serta dorongan-dorongan yang terdapat dalam dirinya agar dapat diterima kelompok dan tidak menganggu kenyamanan orang lain. Kontrol diri merupakan salah satu hal yang dibutuhkan oleh seseorang atau individu untuk bersikap dan mengatasi permasalahannya akibat dari kemampuannya yang terbatas agar sesuai dengan norma di masyarakat dan tidak merugikan orang lain (Khairunnisa, 2013).

Kontrol diri merupakan salah satu benteng bagi remaja untuk mengembangkan dirinya sesuai dengan tuntutan masyarakat. Hal tersebut sebagaimana dikemukakan oleh Santrock (2007) bahwa kenakalan yang dilakukan oleh remaja merupakan akibat dari kegagalan remaja dalam mengembangkan kontrol diri yang cukup dalam hal tingkah laku. Menurut Golfried dan Merbaum (dalam Ghufron dan Risnawati,2014) kontrol diri merupakan kemampuan untuk menyusun, membimbing, mengatur dan mengarahkan perilaku individu ke arah yang positif.

Penelitian ini menunjukkan bahwa sebagian besar responden memiliki tingkat kontrol diri yang cukup baik. Salah satu faktor yang membantu terbentuknya kontrol diri yang baik pada responden adalah faktor teman sebaya. Secara umum siswa di SMA Negeri di Surakarta merupakan siswa-siswa yang memiliki intensitas atau minat yang tinggi terhadap prestasi belajar, kondisi ini menyebabkan adanya kecenderungan siswa untuk lebih fokus atau memprioritaskan perilakunya kepada pencapaian prestasi belajar yang baik. Adanya teman-teman yang memiliki minat di luar pornografi atau kenakalan remaja umum lainnya, membantu responden dalam membentuk kontrol diri yang baik. Hal ini sebagaimana dikemukakan oleh Hurlock (2007) yang menyatakan bahwa faktor eksternal yang membantu pembentukan kontrol diri remaja adalah pola asuh orang tua, lingkungan teman sebaya, pendidikan di sekolah, tingkat religius dan lain-lain. Sedangkan untuk kontrol diri yang kurang baik dapat dipengaruhi oleh kurangnya pengendalian diri, mudah frustasi, mudah meluapkan 
emosi secara meledak-ledak, atau tidak efektif dalam menjalankan aktifitas karena emosi yang tidak terkontrol dan tidak tahan terhadap berbagai tekanan. Sehingga dalam kondisi ini dapat membuat seseorang melakukan hal-hal yang tidak diinginkan yang menuju ke arah negatif seperti pornografi.

4. Peran pengawasan orang tua

Tabel 4 Distribusi frekuensi peran pengawasan orang tua di SMA Negeri di Surakarta.

\begin{tabular}{ccc}
\hline Peran pengawasan orang tua & F & \% \\
\hline Kurang Baik & 62 & 24,8 \\
Baik & 188 & 75,2 \\
Total & 250 & 100 \\
\hline
\end{tabular}

Hasil penelitian menunjukkan bahwa peran pengawasan orang tua di SMA Negeri di Surakarta mayoritas dalam kategori baik yaitu sebanyak 188 orang $(75,2 \%)$. Pengawasan orang tua memiliki kemampuan untuk mempe-ngaruhi keputusan seksual anak-anak mereka terutama keterpaparan materi pornografi. Komunikasi orang tua-anak tentang seks dan hubungan orang tua-anak merupakan faktor penting dalam pembentukan sikap dan perilaku dalam mengakses informasi tentang pornografi yang aman.

Komunikasi orang tua dengan anak memegang peranan penting dalam membina hubungan keduanya. Orang tua yang kurang bisa berkomunikasi dengan anaknya akan menimbulkan konflik hubungan sehingga dapat berdampak pada keterpaparan materi pornografi remaja. Pengawasan orang tua dapat didefinisikan sebagai pengetahuan pengawasan orang tua terhadap kegiatan anak-anak mereka dan apa yang mereka lakukan. Hal ini sama saja dengan bentuk perlindungan orang tua terhadap berbagai risiko keterpaparan materi pornografi yang dilakukan remaja, seperti menonton video porno, membaca tulisan-tulisan atau cerita yang dapat membangkitkan nafsu birahi, dan bahan bacaan yang semata-mata dirancang untuk membangkitkan nafsu birahi atau seks (Firdauz, 2014). Hal ini apabila dibiarkan berlanjut, maka akan dapat berdampak pada perilaku seksual remaja.

Berdasarkan penelitian Hidayah dan Maryatun (2013) mengatakan bahwa pengawasan orangtua merupakan faktor penting yang mempengaruhi perilaku seksual remaja. Pengawasan dari orangtua yang kurang akan mempercepat remaja melakukan hubungan seksual. Remaja yang diawasi orangtuanya akan menunda 
bahkan menghindari hubungan seksual. Sedangkan remaja yang tanpa pengawasan orangtua akan melakukan hubungan seksual pada usia lebih dini.Kecenderungan perilaku seksual remaja semakin meningkat oleh karena adanya penyebaran informasi dan rangsangan seksual melalui media elektronik yang sangat mudah diakses oleh para remaja. Media yang sering digunakan oleh remaja seperti situs porno (internet), video, film porno, serta smartphone (Sarwono, 2013).

Kepala Pusat Pemeliharaan, Peningkatan, dan Penanggulangan Intelgensia Kesehatan Departemen Kesehatan Jofizal Jannis dalam Nadesul (2011) menyatakan bahwa kecanduan pornografi dan narkoba mengakibatkan kegagalan adaptasi. Kecanduan tersebut juga merusak fungsi otak dan struktur otak dengan pola yang sama dengan gejala-gejala fisiologis karena obat-obatan dan alkohol.

Dampak yang akan timbul dari pornografi sangat beragam, secara medis pornografi menyebabkan kerusakan otak, penyimpangan seksual, penyebaran penyakit menular seksual dan penyebaran HIV-AIDS. Pakar bedah syaraf Dr.Donald Hilton, ponografi yang memuat gambaran tentang eksploitasi seks dapat membuat sesorang kecanduan. Jika terus-menerus melihat ponografi setelah melihat untuk pertama kalinya. Kondisi ini, secara ilmu syaraf jika tidak segera diatasi akan mengakibatkan rusaknya fungsi otak bagian depan yaitu pre frontal cortex.Pre frontal kortex mempunyai fungsi sebagai kontrol diri, mengambil keputusan, mengatur emosi, mengorganisasi dan merencanakan (Soebagijo et al., 2009).

\section{Kesimpulan dan Saran}

Sebagian besar siswa mengalami narkolema, Sikap individual remaja yang mengalami narkolema termasuk dalam kategori buruk. Kontrol diri pada remaja dan Peran pengawasan orang tua terhadapan anak terkait dengan narkolema di tergolong baik. Untuk itu diharapkan remaja hendaknya menyadari bahaya akibat pornografi atau narkolema. Guru diharapkan juga melakukan pengawasan dan pendampingan kepada siswanya, khususnya terhadap siswasiswa yang ditengarai memiliki persepsi yang kurang baik terhadap perilaku seksual pranikah akibat dampak dari paparan pornografi dan kontrol diri yang lemah. Orang tua siswa hendaknya lebih mewaspadai dan memperhatikan 
anaknya dalam mengakses media sosial supaya tidak terjerumus ke hal-hal yang tidak baik seperti membuka situs-situs pornografi.

\section{Daftar pustaka}

Firdauz, A.M. 2014. Hubungan Antara Frekuensi Paparan Pornografi Dengan Perilaku Seksual Pranikah Pada Remaja SMA/Sederajat Di Wilayah Kerja Puskesmas Sukawati 1 Kabupaten Gianyar Bali Tahun 2014. Jurnal Inti Sari Sains Medis Vol 2 No. 1.

Aroma, I.S., Suminar, D.R. 2012. Hubungan antara tingkat kontrol diri dengan kecenderungan perilaku kenakalan remaja. Jurnal Psikologi Pendidikan dan Perkembangan, 1(2), 1-6

Azwar, S. 2012. Sikap Manusia Teori Dan Pengukurannya Edisi 2. Jakarta : Pustaka Pelajar.

Wawan. A., Dewi. 2011. Pengetahuan, Sikap Dan Perilaku Manusia. Yogyakarta: Nuha Medika

Ghufron, M. Nur, \& Rini, Risnawati S.2014. Teori-Teori Psikologi. Yogyakarta. Ar-Ruzz Media.

Hidayah, N.F.N dan Maryatun. 2013. Hubungan Antara Pola Asuh Orang Tua dengan Perilaku Seksual Pranikah Pada Remaja di SMK Batik 1 Surakarta. Gaster Vol 10 No.

Nadesul, Handrawan. 2011. Menyayangi Otak Menjaga Kebugaran, Mencegah Penyakit, Memilih Makanan. Jakarta: Penerbit Buku Kompas

Hurlock B.E, 2007. Psikologi Perkembangan Suatu Pendekatan Sepanjang Rentang Kehidupan. Penerbit Erlangga. Jakarta.

Katstleman, M. B. 2015. The Drug Of The New Millineum Narkoba Milieum Baru. Jakarta : Yayasan Kita dan Buah

Masaroh, I., dkk. 2015. Perilaku Sek Remaja Akibat Paparan Media Pornografi. Jurnal kesmasindo. Volume 7 Nomer 3

Nurhayanti, A., E. Normelani., dan S. Adyatama. 2016. Analisis Pengaruh Frekuensi Menonton Blue Film Terhadap Hasil Belajar Mahasiswa. Prosiding Seminar Nasional Vol 2 No. 1.

Ruspawan, D.,M , \& Putra, P., D. 2013. Sikap Remaja Sehubungan Media Pornografi Dengan Perilaku Seks Pranikah. Jurnal Keperawatan Sarwono, S. W. 2013. Psikologi Remaja. Jakarta : Rajawali Pers. 
Soebagijo, A., W. Pahlemy., Y. Sriwartini dan Asmawati. 2009. Ayo Ajak TemanTeman Kita Sadari Bahaya Pornografi. Jakarta : Kementerian Pemuda dan Olahraga.

Susanto. 2013. Hubungan Atara Sikap Terhadap Media Pornografi Dengan Perilaku Pranikah Pada Remaja. Empathy Jurnal Fakultas Psikologi. Volume 2 no 1.

Wulandari, C. 2017. Hubungan Kejadian Narkolema dengan Motivasi Belajar pada Remaja di SMK N 7 Surakarta. Skripsi. STIKES 'Aisyiyah Surakarta : Surakarta

Yutifa, H., Dewi, A.P dan Misrawati. 2015. Hubungan Paparan Pornografi Melalui Elektronik Terhadap Perilaku Seksual Remaja. JOM Vol 2 No. 2 